\title{
The Effect of Company Characteristics and Corporate Governance on the Practices of Intellectual Capital Disclosure
}

\author{
Isnalita, Fitri Romadhon \\ Departement of Accountancy, Universitas Airlangga. Jl. Airlangga 4-6, Surabaya
}

\begin{tabular}{l} 
A R T I C L E I N F O \\
\hline Keywords: \\
Company characteristics, \\
Corporate governance structure, \\
Intellectual capital disclosure \\
Kata Kunci: \\
karakter perusahaan, \\
struktur corporate governance, \\
intellectual capital disclosure
\end{tabular}

Corresponding author: isnalita@feb.unair.ac.id

\section{A B S T R A C T}

This study aimed to reveal the effect of company characteristics, company size i.e., profitability, leverage, liquidity, and industry type; and corporate governance structure, consisting of the audit firm size and the independent commissioners' composition, on the intellectual capital disclosure. This research applied quantitative approach by testing seven independent variables through multiple linear regression analysis. The samples taken were 80 annual reports from companies listed in the LQ-45 index in the year 2012-2013. The method employed to select the samples was purposive sampling. Content analysis was applied to analyze the intellectual capital disclosure. This study revealed that only the company size showed significant positive impact to the disclosure of intellectual capital, while profitability, leverage, liquidity, industry type, the audit firm size, and the independent commissioners composition did not bring significant effect. In addition, based on the results of content analysis it can be concluded that the intellectual capital disclosure is quite low, amounting to $46.9 \%$, with relational capital amounted to $34.74 \%$, $32.54 \%$ of structural capital, and human capital reached $32.71 \%$.

\section{SARI PATI}

Penelitian ini bertujuan untuk mengetahui pengaruh karakteristik perusahaan, yaitu ukuran perusahaan, profitabilitas, leverage, likuiditas, dan tipe industri, serta struktur corporate governance, yang terdiri dari ukuran komite audit, dan komposisi komisaris independen terhadap intellectual capital disclosure. Pendekatan penelitian yang digunakan adalah pendekatan kuantitatif, dengan menguji tujuh variabel independen melalui analisis regresi linier berganda. Sampel yang digunakan adalah 80 laporan tahunan dari perusahaan yang terdaftar dalam indeks LQ-45 pada tahun 2012-2013. Metode yang digunakan untuk pemilihan sampel adalah purposive sampling. Content analysis digunakan untuk menganalisis intellectual capital disclosure. Penelitian ini memberikan hasil bahwa hanya ukuran 
perusahaan yang berpengaruh signifikan positif terhadap intellectual capital disclosure, sedangkan profitabilitas, leverage, likuiditas, tipe industri, ukuran komite audit, dan komposisi komisaris independen tidak berpengaruh signifikan. Selain itu berdasarkan hasil content analysis dapat disimpulkan bahwa intellectual capital disclosure masih cukup rendah, yaitu sebesar 46,9\%, dengan relational capital sebesar $34,74 \%$, structural capital 32,54\%, dan human capital 32,71\%.

(C) 2018 IRJBS, All rights reserved.

\section{INTRODUCTION}

The changes in the business trend tend to be knowledge-based oriented by prioritizing creation of values for all activities in a company. As a consequence, the terms financial capital and physical capital become less significant compared to intellectual capital (Sawarjuwono \& Kadir, 2003). Intellectual capital becomes an important component for a company to gain competitive advantages because this capital is unique, and not easily imitated.

The shifts make knowledge-based assets an important element to be included in financial statements rather than merely reporting physical assets. This phenomenon is highlighted by a research that suggests financial statements as insufficient to meet the needs of the users and are less relevant to be used as guidelines in making decisions (Oliveira, Rodrigues, \& Craig, 2006). Some studies also mention that the present financial statements are full of information asymmetries, and considered as incapable of revealing the key factors of the company's long term value, which is the intangible resources. These information asymmetries resulted in the irrelevance of the financial statements as the information source for investors. Therefore, other components are needed to improve the quality of information, and one of them is intellectual capital disclosure. Pricewaterhouse Coopers survey indicates that information regarding intellectual capital is one of the ten information needed by users (Eccles et al., 2001 in Suhardjanto \& Ward, 2010).
The urgency of revealing and investor interest towards intellectual capital is not comparable with existing practices in Indonesia. Although a research conducted by Purnomosidhi (2005), showed an increase in intellectual capital disclosure in several companies listed on the Indonesia Stock Exchange (BEI), but in general the presented content-related intellectual capital is still low. Similar to a research conducted by Suhardjanto and Ward (2010), Purnomosidhi (2005), indicated that the level of intellectual capital disclosure by listed companies in Indonesia is still less than $50 \%$. One of the factors causing this low intellectual capital disclosure is the high cost of the disclosure.

In addition to poor disclosure practices, the disclosure of intellectual capital also varies from one company to another. One factor that is quite dominant is the characteristics of the company. The company characteristics mostly include financial characteristics, industry type, and company size. Some researchers have proved that company characteristics affect the level of intellectual capital disclosure (Purnomosidhi (2006), Suhardjanto and Ward (2010), Ousama, Fatima \& Hafiz-Majdi (2012)). Previous research showed that there are inconsistent variables against the practice of intellectual capital disclosure related to the characteristics of the company, such as leverage, company size and industry type.

Although research on intellectual capital disclosure is common in the international sphere, 
this topic is an interesting research object, since the disclosure of intellectual capital is still voluntary in nature and relatively small in number. Further, the financial accounting standards have no fixed regulations on intellectual capital. Another motivation underlying the researchers to explore this topic is to contribute empirically to the intellectual capital disclosure practices in Indonesia.

\section{Literature Review And Hypotheses Development Agency Theory}

Agency theory is a theory that explains the relation between the principal of an entity and the manager (agent). This theory explains the reasons managers disclose information to shareholders (Wallace, Naser, \& Mora, 1994). Agency theory provides a framework that can connect the voluntary disclosure of corporate governance, namely by using a mechanism that can reduce the costs occur as a result of conflict between managers and shareholders, and the conflict between the company and its creditors. The mechanism may be in a form of report which can be used to monitor all activities, namely to reveal more voluntary information such as intellectual capital disclosure (Oliveira et al., 2006).

\section{Stakeholder Theory}

Stakeholder theory provides a point of view that a disclosure is a mechanism for maintaining a good relationship between the company and its stakeholders. It is also a strategy to realize a certain interest. Stakeholder theory function is to assist company managers in understanding the stakeholder environment in a bid to create an effective relationship, evaluating the impact of all activities undertaken intended to create a useful value for the company and minimize the risk that may befall to the stakeholders.

\section{Signaling Theory}

Signaling theory assumes that information disclosure is a reaction against information asymmetries on the market. The reason that may cause information asymmetries is the internal company knows more about company's information compared to the external parties, namely investors, creditors, and other stakeholders. As a consequence, the external parties will try to protect themselves by giving a low value to the company. In anticipation of such action, companies can increase their value by reducing the information asymmetries through information disclosure, one of which may include financial information (Wolk, Tearney, \& Dodd, 2000).

\section{Intellectual Capital}

Intellectual capital can be identified as a set of intangible assets that includes resources, capabilities and competencies to increase the performance and create value for the organization (Bontis, 2001). Some forms of intellectual capital disclosure are invaluable information for investors, because the information can reduce uncertainty about the future and facilitate an accurate assessment of the company (Bukh, Nielsen, Gormsen, \& Mouritsen, 2005). The invaluable information which are not normally shown on the balance sheet include internal structures (organizational capital), external structure (customer / relational capital), and employee competence (human capital) (Sveiby, 1997; Li et al., 2008)

\section{Company Characteristics}

Company characteristic variations lead to the relevance and urgency of different disclosures in each company. Some company characteristics discussed in this study are the size, the profitability, the leverage, the liquidity, and the industry type. The company size is related to the measurement of a company. While profitability is one indicator to assess the company's ability to generate profits and increase shareholder value. Leverage is the company's overall unfulfilled financial obligations to the other parties in which leverage is the source of a company's funding from creditors. Liquidity refers 
to a company's ability to meet its short-term obligations. Classification of the type of industry can be done using criteria derived from a research conducted by Bukh et al. (2005), that classifies the types of industry into two: the High Tech and NonHigh Tech.

\section{Corporate Governance}

Corporate governance is the set of rules defining the relationship between shareholders, managers, creditors, governments, employees, the internal and external parties regarding their rights and obligations, or a system by which the company can be directed and controlled. Agency theory is a theory that provides a framework for linking the voluntary disclosure with corporate governance, in which the control mechanism is designed to reduce the agency problems arising from the separation between the owner and the management (Welker, 1995 in Li, Pike, \& Haniffa, 2008).

The mechanism in question is reflected in the corporate governance structure comprising of the audit committee and board of commissioners. The audit committee is the board operating committee responsible for executing the oversight function of financial reporting and disclosure. Meanwhile, the board of commissioners is the core of corporate governance, which is the party given the task to ensure the implementation of company strategy, oversees the company's operated by the management, and the implementation of accountability.

\section{Size Effects on Intellectual Capital Disclosure}

The larger the company size, the demand for information disclosure is also higher compared to smaller companies. This is consistent with agency theory which states that agency costs in large companies are higher than that of small ones. Larger companies also tend to have a conflict between corporate managers and stakeholders, which in turn, increase the agency costs. Therefore, the company voluntarily discloses more information, including information on intellectual capital, to reduce the agency costs (Ousama et al., 2012). Research conducted by Nurunnabi, Hossain, \& Hossain (2011) and Ousama et al., (2012) demonstrate the positive significance between company size and the intellectual capital disclosure. In contrast, the study by Singh \& Van der Zahn (2008) concluded that the company size brought negative effect on the intellectual capital disclosure.

H1: Size significantly affects the intellectual capital disclosure.

\section{Profitability Effects on Intellectual Capital Disclosure}

Meek et al. (in Purnomosidhi, 2005) revealed that the indicator used to differentiate companies with high profitability and low profitability is through the level of voluntary disclosure. The theory supports the relation between profitability and intellectual capital disclosure is signaling theory. Profitable companies have the benefit of signaling that the company is performing better than any other companies. The signals can be in the form of information about intellectual capital. In addition, one of the factors that cause a company to have a higher profit is the intellectual capital owned. Therefore, it is possible for the company to reveal information related to intellectual capital (Ousama et al., 2012). The research conducted by Ousama et al. (2012) and Suhardjanto and Ward (2010) showed that profitability has a positive significant effect on the intellectual capital disclosure. Meanwhile, a research conducted by Ramadan \& Majdalany (2013) showed a negative relationship.

H2: Profitability significantly affects on Intellectual Capital Disclosure

\section{Leverage Effects on Intellectual Capital Disclosure} Research on the relation between leverage and intellectual capital disclosure, from year to year always provided various results. The research conducted by Suhardhjanto and Ward (2010), Ousama et al. (2012), and Whiting \& Woodcock, (2011) show that leverage gives no significant 
effect. While the study of Bruggen, Vergauwen, \& Dao (2009), found that there was a significant positive relation between leverage and intellectual capital disclosure. Agency theory can be used to explain the relation between the breadth of the disclosure and leverage. Companies with high leverage have high agency costs associated with high risk, such as the possibility of financial distress (Jensen \& Meckling, 1976). Thus, creditors and other parties such as bondholders, will ask for more information to reduce information asymmetries. Consequently, companies with higher leverage is expected to have higher incentive in disclosing voluntary information with higher intensity, one of which includes the intellectual capital disclosure, in order to reduce agency costs, like the cost of supervision and to help to convince creditors that their needs will be fulfilled (Hanifa \& Cooke, 2002, in Whiting \& Woodcock, 2011).

H3: Leverage significantly affects on

the intellectual capital disclosure

\section{Liquidity Effects on Intellectual Capital Disclosure}

Companies with low liquidity positions will reveal more information to justify their liquidity status. Based on research by Cooke (1989), companies with higher liquidity tend to disclose more information to convince stakeholders that the company is aware of the present problems (Wallace et al, 1994 Alsaeed, 2006). The argument is supported by the signaling theory, in which companies with high liquidity posses higher incentive in providing elaborate explanation in their annual report as a signal on their ability to meet short-term financial obligations.

H4: Liquidity significantly affects the intellectual capital disclosure.

\section{Industry Type Effects on Intellectual Capital Disclosure}

Signaling theory can be used to explain the reason why a company in a certain industry may reveal more information. A company is expected to send positive signals by providing as much information as possible as an evidence that the company has conducted the best practices in an industry (Watson et al, 2002 in Ousama et al., 2012). When a company in an industry failed the practice of disclosures conducted by similar companies, it could be regarded as a signal that the company deliberately concealed information regarding bad news.

The relation between the industry type and intellectual capital disclosure can be clarified using stakeholder theory, in which stakeholders are entitled to obtain information about the activities of the company which could affect their interests (Guthrie et al, 2004 in Whiting \& Woodcock, 2011). Some research suggested that technology or knowledge-based industries have the tendency to reveal more intellectual capital disclosure, such as the research conducted by Bozzolan, Favotto, \& Ricceri (2003); Petty and Cuganesan, (2005); and Oliveira et al., (2006)

H5: Industry type significantly affects

the intellectual capital disclosure.

\section{The Audit Committee Size Effects on Intellectual Capital Disclosure}

An audit committee is established to supervise and control effectively the validity of accounting information and assure the quality of information disclosed (McMullen, 1996 in Nurunnabi et al, 2011). An effective audit committee should be able to improve internal control and act as a party with the power to oversee the activities in the company to enhance the value relevant to intellectual capital disclosure.

H6: The size of the audit committee significantly

affects the intellectual capital disclosure

\section{The Board of Commissioners Composition Effects} on Intellectual Capital Disclosure

One important role of the board of commissioners is to reduce information asymmetries, between owners and agents. Board of commissioners is expected to protect investor interests related to decision making and to ensure that the management policy is in line with the investor 
interests. More disclosures can reduce uncertainty for investors and information asymmetries. Independent commissioners can positively influence the disclosure.

Previous studies regarding voluntary disclosures that consider the composition of the board of commissioners as determinants of voluntary disclosure widely varies. Some found that the proportion of members of the board of directors comprising of independent commissioners positively related to the ability of the board of commissioners to influence voluntary disclosure decisions, as shown by Chen \& Jaggi (2001) (in Li et al., 2008). The research conducted by Ho \& Wong, 2001 (in Li et al., 2008) found that there was no relation between the independent commissioner composition with intellectual capital disclosure.

H 7: The composition of the board of commissioners significantly affects on the intellectual capital disclosure

\section{METHODS}

\section{Types and Data Sources}

The data analysed in this research is secondary data which was taken from annual reports of companies included in the LQ-45 index of the year period 2012 to 2013.

\section{Sampling technique}

The data collection method applied in this study was purposive sampling using criteria set by the researchers. The criteria of sampling research were as follows:

1. Companies listed in Indonesia Stock Exchange and is included in the LQ-45 index for the period of February 2012 - July 2012; August 2012 - January 2013; February 2013 - July 2013; and in August 2013 - January 2014

2. Companies that published complete annual report for the year 2012 and 2013, which were officially audited and published and can be downloaded via the official website IDX, and the company's website.

3. The companies selected to be the samples were non-banking, non-financial compa-

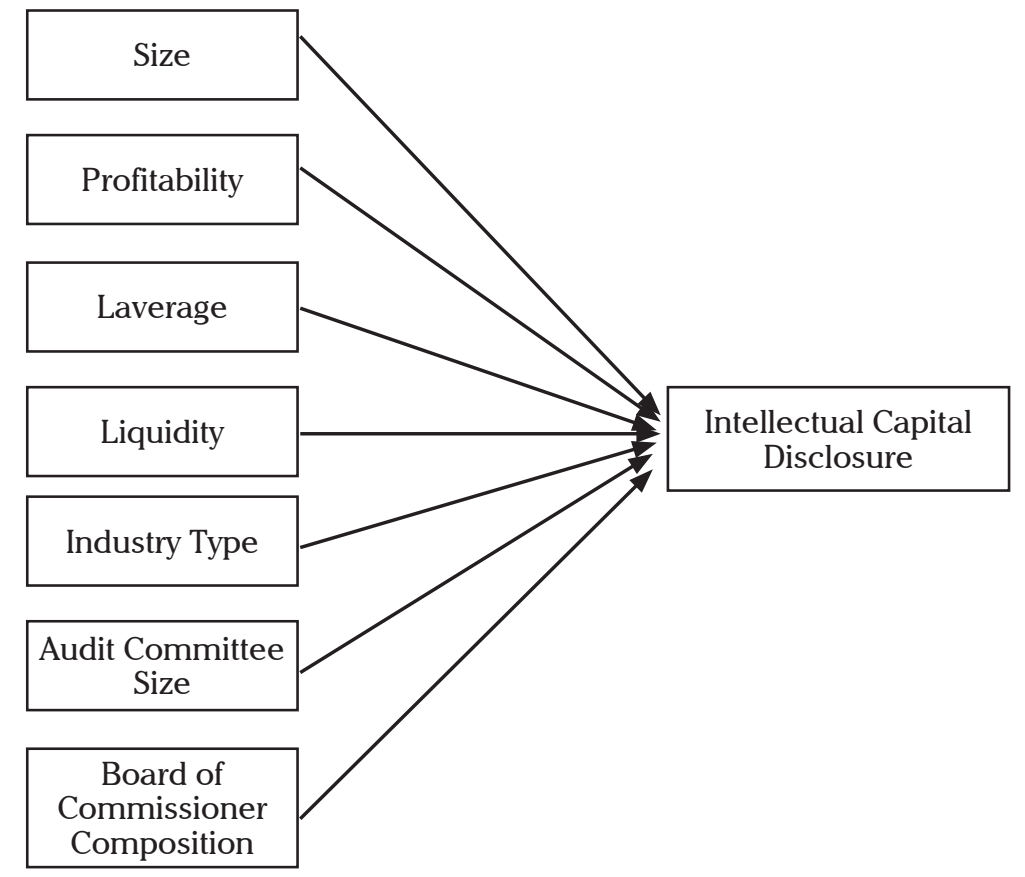

Figure 1. Conceptual Framework 
Tabel 1. Variable Operational Definition

\begin{tabular}{|c|c|c|c|}
\hline $\begin{array}{c}\text { Independent } \\
\text { Variables }\end{array}$ & Operational definition & Proxy & $\begin{array}{l}\text { Measurement } \\
\text { Scale }\end{array}$ \\
\hline Size & $\begin{array}{l}\text { Size is proxied by using the natural logarithm of the } \\
\text { total assets of the company (Hanifa \& Cooke, 2002) }\end{array}$ & $\begin{array}{l}\text { Natural log of total } \\
\text { assets }\end{array}$ & Ratio \\
\hline Profitability & $\begin{array}{l}\text { ROA measures the company's ability to use its } \\
\text { assets to generate net profit (Hanafi \& Halim, } \\
\text { 2009). }\end{array}$ & $\begin{array}{l}\text { ROA }=\text { Net profit } / \\
\text { Total assets }\end{array}$ & Ratio \\
\hline Leverage & $\begin{array}{l}\text { Debt to equity ratio shows the company's ability } \\
\text { to meet its long-term obligations and how well } \\
\text { creditors can be protected (Hanafi \& Halim, 2009). }\end{array}$ & $\begin{array}{l}\text { D / E Ratio = Total } \\
\text { liabilities / Total } \\
\text { shareholder's equity }\end{array}$ & Ratio \\
\hline Liquidity & $\begin{array}{l}\text { Liquidity shows the company's ability to meet its } \\
\text { short-term liabilities. In this study, liquidity will be } \\
\text { proxied by using the current ratio (Alsaeed, 2006). }\end{array}$ & Current Ratio & Ratio \\
\hline Industrial Type & $\begin{array}{l}\text { The company will be classified based on the } \\
\text { Global Industry Classification Standard (GICS), } \\
\text { which recognizes two types of industries, those } \\
\text { that belong to high-tech (knowledge intensive } \\
\text { industries) or low-tech (Whiting \& Woodcock, } \\
\text { 2011). }\end{array}$ & $\begin{array}{l}1=\text { high-tech } \\
\text { industry } \\
0=\text { low tech } \\
\text { industry }\end{array}$ & Nominal \\
\hline $\begin{array}{l}\text { Audit } \\
\text { Committee Size }\end{array}$ & $\begin{array}{l}\text { Variable size of the audit committee is measured } \\
\text { by counting the number of audit committee } \\
\text { members (Felo et al., 2003, in Uzliwati, } \\
\text { Suhardjanto, \& Djati, 2014). }\end{array}$ & $\begin{array}{l}\text { The number of } \\
\text { independent } \\
\text { commissioners on } \\
\text { the audit committee }\end{array}$ & Ratio \\
\hline $\begin{array}{l}\text { Composition } \\
\text { of the Board of } \\
\text { Commissioners }\end{array}$ & $\begin{array}{l}\text { The composition of the board of commissioners } \\
\text { can be proxied by the number of percentage } \\
\text { of the board of commissioners coming from } \\
\text { external company (independent commissioner) } \\
\text { compared to the total members of the board of } \\
\text { commissioners in the company. The expected } \\
\text { result is at least } 30 \% \text { which is in accordance with } \\
\text { the requirements of BEI. }\end{array}$ & $\begin{array}{l}\text { The number of } \\
\text { independent } \\
\text { commissioners } \\
\text { is divided by the } \\
\text { total members } \\
\text { of the board of } \\
\text { commissioners }\end{array}$ & Ratio \\
\hline
\end{tabular}

nies. This criterion is set because the banking and finance industries have special characteristics and regulations.

4. The companies did not discontinue their activities in the capital market, and did not terminate their operations during 2012-2013.

5. The company owned the necessary data and information, including the variables under research.

\section{Research variables}

Dependent variables are used for this research. This is the breadth of intellectual capital disclosure (ICD). The instrument used in this study refers to the components of intellectual capital declared by Sveiby (1997), and refers to the study of Li et. al., (2008), namely internal structures (organizational capital), external structure (customer / relational capital), and employee competence (human capital). ICD was measured by using the unweighted disclosure index, assuming that all of the items are of the same value. To assess the level of intellectual capital disclosure, the disclosure score is applied by giving a value to the items disclosed in the annual report. Based on these procedures, the disclosure of certain item that explain the intellectual capital disclosure in the annual report gain a score of 1 . Whereas, if the 
item was not disclosed the score was 0 . The breadth of the disclosure is the ratio of the information items found in the annual report divided by the maximum number of items of information on the disclosure index. Thus, the measurement of the breadth of intellectual capital disclosure can be calculated by the following formula (Ousama et al., 2012)

$$
\operatorname{ICDS}=\frac{\text { TADS }}{\text { MRD }}
$$

Where:

$$
\begin{aligned}
\text { ICDS = } & \text { the intellectual capital disclosure index } \\
\text { TADS = } & \text { total actual disclosure scores for } \\
& \text { each company, by providing: a score } \\
& \text { of } 1 \text { if there is a intellectual capital } \\
& \text { disclosure items; score } 0 \text { if not } \\
\text { MRD = } & \text { maximum disclosure items (61 items) }
\end{aligned}
$$

The independent variable of this research consisted of size, profitability, leverage, liquidity, industry type, size and composition of the audit committee and of the board of commissioners. The definition of each operational independent variable is further explained through the table 1.

\section{Data collection Method}

Method of data collection applied in this research was the content analysis method which is used to assess the frequency and types of intellectual capital disclosure. The level of reliability for content analysis based on Cronbach's a (cronsbach's alpha) with a value of +0.60 as the minimum threshold of acceptable reliability, as a construct can be said to be reliable if the value Cronbach's alpha $>0.60$ (Ghozali, 2006).

\section{Data analysis technique}

This study used multiple regressions analysis technique, with the analysis model as follows:

$\mathrm{ICD}=\alpha+\beta 1 \mathrm{SIZE}+\beta 2 \mathrm{PRFT}+\beta 3 \mathrm{LEV}+\beta 4 \mathrm{LIK}+$ $\beta 5 \mathrm{TI}+\beta 6 \mathrm{KA}+\beta 7 \mathrm{DK}+\varepsilon$
Where the ICD is the Intellectual Capital Disclosure, SIZE is the size of the company, PRFT is profitability, LEV is leverage, LIK is liquidity, TI is the industry type, KA is the size of the audit committee, and DK is the composition of the board of commissaries.

\section{Hypothesis testing}

The test is conducted by measuring the goodness of fit regression model, to assess the accuracy of the sample regression in estimating the actual value. The steps to measure the goodness of fit is by calculating the coefficient of determination $\mathrm{R}^{2}$ and $\mathrm{t}$ test.

\section{RESULTS AND DISCUSSION \\ Research Object Description.}

Based on the criteria specified, there were found 50 listed companies which were included in the LQ-45 index for the period 2012-2013. Since every 6 months there are always updates of companies that enter the LQ-45 index, then not every year a company can enter the LQ-45 index.

Tabel 2. Sample Selection Criteria

\begin{tabular}{lc}
\hline Sample criteria & amount \\
\hline $\begin{array}{l}\text { Companies listed in Indonesia } \\
\text { Stock Exchange and is included }\end{array}$ & \\
in the LQ-45 index for the period & \\
February 2012 - July 2012, August & 90 \\
2012 - January 2013, February 2013 & \\
- July 2013, August 2013 - January \\
2014 \\
\hline $\begin{array}{l}\text { The company did not publish the } \\
\text { annual report for the year 2012 }\end{array}$ \\
\hline \begin{tabular}{l} 
Finance and banking companies \\
\hline
\end{tabular} \\
Total sample
\end{tabular}

\section{Descriptive Analysis}

Based on the results of the descriptive analysis, it was calculated that intellectual capital disclosure (ICD) has an average value of $46.91 \%$. The value indicates that on the average companies reveal at $46.91 \%$ or about 27 items 
Tabel 3. Descriptive Statistics

\begin{tabular}{lrrrrr}
\hline & $\mathrm{N}$ & Minimum & Maximum & Mean & Std.Deviaton \\
\hline Size & 81 & 28.43 & 33.00 & 30.5734 & .89669 \\
\hline ROA & 81 & -.27 & .40 & .0937 & .10426 \\
\hline Leverage & 81 & -24.12 & 17.5 & 1.1140 & 3.7832 \\
\hline Liquidity & 81 & .38 & 6.44 & 2.1680 & 1.50792 \\
\hline Industry Type & 81 & 0 & 1 & .47 & .502 \\
\hline DK Composition & 81 & .25 & .80 & .4097 & .11313 \\
\hline The size of the audit & & & & & .548 \\
committee & 81 & 1 & 3 & .4691 & .13304 \\
\hline ICD & 81 & .23 & .72 & & \\
\hline Valid N (listwise) & 81 & & & & \\
\hline
\end{tabular}

out of 61 items in their annual report. While the independent variable on company size has an average size of 30.5734 with a standard deviation of .89669 . This value reflects that the average the companies are of medium size. It is also revealed that the average profitability of the sample companies is 0.0937 with a standard deviation of 0.10426 . The higher the standard deviation, the company's ability to use assets to generate net profit is better compared to other companies used as samples.

It is known also that the average leverage on the company samples is 1.1140 with a standard deviation of 3.7832 . This means that most companies listed in the LQ-45 index have a balanced proportion between the use of debt and equity. Meanwhile, the average liquidity in the samples is 2.1680 with the standard deviation of 1.50792, where the higher the standard deviation the higher the company's ability to meet the current liabilities. Industry type variable shows an average of 0.47 with a standard deviation of 0.502 . The maximum value for the industry type variable is 1 which is given to high-tech companies. There are 23 companies belong to this category. The minimum value of 0 is given to the low tech companies that in this study is amounted to 27 companies.

\section{RESULTS AND DISCUSSION}

Based on the reliability test, the Cronbach alpha value received is 0.882 which is greater than +0.60. The higher value indicates that the results of content analysis in this study is accurate and trustworthy. Based on the content analysis results, information on the composition of the intellectual capital disclosure is gained. The details are $32.716 \%$ in the form of human capital, $32.543 \%$ in the form of structural capital, and $34.741 \%$ in the form of relational capital. Among the three types of categories of intellectual capital disclosure, relational capital is mostly disclosed, amounting to $34.741 \%$. Disclosures about the relational capital, which is the biggest proportion, indicate that companies tend to put more emphasis on disclosures related to external parties, such as the relation with customers, market shares, distribution channels.

Human capital is the second largest portion with a percentage of $32.716 \%$. This considerable composition indicates that companies are increasingly aware of the importance of human existence. This is supported by the high percentage, of $95 \%$, on the item relation with employees, which is defined as the recognition of the importance of employees, rewards to employees, employee satisfaction, loyalty and the work environment safety. 
Meanwhile, structural capital has the smallest composition which is $32.543 \%$. Information on structural capital is information that reflects the characteristics of the company, and how the management creates value or competitive advantages. Despite the fact that this information offers an added value to the company, some companies are reluctant and concern more on the possible risks if the companies reveal their internal information. One of the possible risk is that with more disclosure, the company's competitors may benefit from the provided information.

\section{Hypothesis testing}

In this research, four classic assumption tests consist of normality test, multi-co-linearity test, hetero kedastisity, and autocorrelation test were employed. It can be concluded that the normality assumption is fulfilled, no multi-co-linearity and heterokedastisity data, and there is also no autocorrelation among residual values.

Based on the regression result, the regression equation model is generated as follows:

$\mathrm{ICD}=-1.406+0.063 \mathrm{Size}+0.247 \mathrm{ROA}-0.002 \mathrm{LEV}$

$-0.11 \mathrm{LQ}+0.027 \mathrm{TI}-0.027 \mathrm{KDK}+0.015 \mathrm{UKA}$ $\mathrm{t}$ value calculated for the size variable is equal to 4.089 with significant value $0.000<0.005$ then $\mathrm{H} 1$ is accepted and can be concluded that there is a significant relation between the size of the company and the intellectual capital disclosure. Profitability produces a $\mathrm{t}$ value of 1.782 with a significance value of $0.079>0.05$. This value indicates that $\mathrm{H} 2$ is rejected and it can be concluded that there is no significant relation between profitability and intellectual capital disclosure. Leverage has t value of -0.576 with a significance value of $0.566>$ 0.05 . The significance value indicates that the $\mathrm{H} 3$ is rejected, in other words, there is no significant relation between leverage and intellectual capital disclosure. Liquidity has a t value of -1.176 with a significance value of 0.244 . The significance value is higher than 0.05 . This means that the $\mathrm{H} 4$ is rejected and it can be concluded that liquidity does not significantly influence the intellectual capital disclosure.

Industry type has a $t$ value of 0.1006 with a significance value of $0.318>0.05$, so $\mathrm{H} 5$ is rejected and it can be concluded that the type of industry does not significantly influence the intellectual capital disclosure. The size of the audit committee has a t value of 0.581 with a significance value

Tabel 4. Results of Multiple Regressions Analysis

\begin{tabular}{lccrr}
\hline \multicolumn{1}{c}{ Model } & Coefficient & $\begin{array}{c}\text { Standard } \\
\text { coefficient }\end{array}$ & t & Sig. \\
\hline Constants & -1.406 & & $-2,981$ & 0.004 \\
\hline Size & 0.063 & 0.425 & 4,089 & $0,000^{*}$ \\
\hline ROA & 0.247 & 0.194 & 1,782 & $0.079 * *$ \\
\hline Leverage & -0.002 & $-0,058$ & -0.576 & 0.566 \\
\hline Liquidity & -0.011 & -1.25 & $-1,176$ & 0.244 \\
Industry Type & 0.027 & 0.102 & 1,006 & 0.318 \\
\hline DK Composition & -0.204 & -0.173 & $-1,718$ & $0.090 * *$ \\
\hline Audit Committee Size & 0.015 & 0.061 & 0.581 & 0.563 \\
\hline R & & & & \\
\hline R Square & $=0.540$ & & & \\
\hline
\end{tabular}

Dependent variable: Intellectual Capital Disclosure

$*$ = significant at the level $5 \%$

$* *=$ significant at the level of $10 \%$ 
of $0.563>0.05$. This value indicates that the $\mathrm{H} 7$ is rejected and it can be concluded that the size of the audit committee does not significantly influence the intellectual capital disclosure. The composition of the board of commissioners produces a $t$ value of -1.718 with a significance value of $0.09>0.05$. This means that $\mathrm{H} 6$ is rejected and it can be concluded that the composition of the board of directors does not significantly influence the intellectual capital disclosure. Those seven independent variables were tested partially, i.e. by using $\mathrm{t}$ test. Based on $\mathrm{t}$ test, it can be concluded that only the size of a company that has a significant influence on the intellectual capital disclosure.

The Company Size Influence on the Intellectual Capital Disclosure

The results of hypothesis testing showed that the company size had a significant influence with significance level 0.000 and coefficient 0.063. That means, the larger the size of the company, the level of disclosure of intellectual capital also increases. Compared to smaller companies, larger companies tend to have a good internal management information system, linked to a wide range of activities. Therefore, the larger companies have better ability to disclose information. The results of this study support previous research showing a significant positive relation between company size and intellectual capital disclosure. (Ousama et al., 2012; Purnomosidhi, 2005; Suhardjanto \& Ward, 2010; Nurunnabi et al, 2011) While the study was not consistent with the results Bozzolan et al. (2003), Bukh et al, (2005).

The Profitability influence on the Intellectual Capital Disclosure

The results of research had illustrated that profitability did not significantly influence the intellectual capital disclosure. Thus, the level of profitability does not affect intellectual capital disclosure. This research is in line with the research conducted by Purnomosidhi (2005) and
Lina (2013). On the other hand, this study does not support research conducted by Ousama, et al., (2012), Suhardjanto \& Ward (2010), Ramadan \& Majdalany (2013). This study does not support signal theory, since low level of profitability is not an inhibiting factor to disclose voluntary information in a bid to indicating a signal on the company performance or information disclosure owned by the company. Companies with high level of profitability tend to limit information in order to anticipate competitors' move, as the information may be used to imitate the creativity, ideas, innovations, which may jeopardize the company's competitive advantage.

The Leverage influence on the Intellectual Capital Disclosure

Hypothesis testing results showed that the leverage did not have a significant influence on the intellectual capital disclosure. This study supports research conducted by Ousama et. al., (2012), Nurunnabi (2011), Fatima \& Purnamasari (2012), Suhardjanto \& Ward, (2010), Whiting \& Woodcock (2011). Insignificant influence may happen due to the company's strategy, other than the intellectual capital disclosure or other communication tools, to reduce conflict between capital providers and managers, so that the agency costs which may be incurred as a result of the high degree of leverage can be reduced. In addition, the company also considers the costs and benefits incurred by the existence of intellectual capital disclosure.

\section{The Liquidity influence on the Intellectual Capital} Disclosure

Based on the results of hypothesis testing, it can be concluded that liquidity does not have an influence on the intellectual capital disclosure. The results support the research conducted by Nurunnabi et. al., (2011). Liquidity as a performance benchmark can be interpreted that companies with a higher level of liquidity tend not to disclose more information. Meanwhile, companies with a lower liquidity level, have greater pressure to explain 
their ability (Wallace et al., 1994). This insignificant relation may be caused by higher liquidity value, which is not always meant a good signal, good news or an incentive for companies to disclose extensive information.

\section{The Industry Type influence on Intellectual Capital Disclosure}

The results showed that the industry type was not a factor capable of explaining the variation of intellectual capital disclosure. The results of this study support the research conducted by Purnomosidhi (2005). Industries that conduct intensive research and development activities revealed a relatively similar amount of information regarding intellectual capital as companies which are not research-intensive ones. The results of this study do not correspond to the research conducted by Ousama et al., (2012), Petty \& Curganesan (2005), Whiting \& Woodcock (2011).

This study also does not support signal theory, which stated that the company is expected to send a positive signal by providing elaborate information as an evidence of the company's best practices in an industry. This may be related to the company's logic that a company can reduce the level of intellectual capital disclosure as an attempt to eliminate a signal to competitors and other parties, to maintain the company's competitive edge. For example, a high level of intellectual capital, can be obtained from the creativity and innovation of employees.

The Size of the Audit Committee Influence on the Intellectual Capital Disclosure

The results showed that the size of the audit committee did not significantly influence the intellectual capital disclosure. This study does not support research conducted by $\mathrm{Li}$ et al., (2008). But this study is consistent with the research conducted by Taliyang \& Jusop (2011), Zulkarnaen \& Mahmoud (2013) and Hidalgo, RGarcia-Meca, \& Martinez (2011). The existence of audit committees within a company can not be separated from the regulations issued by Bapepam no. KEP 29 / PM / 2004 on the existence of an audit committee. The regulations indicate that the existence of audit committees in companies established in Indonesia is only to fulfill the government requirement, so that in real practice the function of an audit committee is not effective. Another reason that could explain the insignificant relation is that the independent commissioners who are inside the audit committee, are not fully able to carry out their duties independently (Taliyang \& Jusop, 2011).

\section{The Composition of the Board of Commissioners} Influence on Intellectual Capital Disclosure

Based on the hypothesis testing, the composition of the board of directors did not affect the intellectual capital disclosure. This study is in line with the research conducted by Suhardjanto \& Ward (2010), Fatima \& Purnamasari (2012) and Hidalgo et al., (2011). The existence of independent commissioners are supposed to be supporting the principle of responsibility, namely through the intellectual capital disclosure as the implementation of good corporate governance. However, the results found is the opposite. Therefore, the implementation of corporate governance is still questionable. This insignificant influence may be due to the fact that the board of commissioners relating to voluntary disclosure may only happen in a highly proactive environment to disclose information, which is for the government with top anti-directors (outside investors) rights and excellent law enforcement atmosphere.

\section{MANAGERIAL IMPLICATIONS}

Based on the finding, it can be seen that companies listed in the LQ-4 index have revealed intellectual capital, but the average disclosure is still relatively low at $46.91 \%$, or reveal about 27 items from a total of 61 items should be disclosed. The result is certainly not in accordance with the level of disclosure expected by stakeholders to be able to provide information not only limited to financial information such as information about the mana- 
gement of resources owned by the company, business processes, relationships with external parties. Though the company incorporated in the LQ-45 index is considered as a company with characteristics of a very good company by the market. However, most companies only disclose compulsory information, the company's awareness to disclose voluntary information is still relatively low.

Through the intellectual disclosure, stakeholders can obtain information that can be used to evaluate the company's performance or assess the company's potential in the future. For example, when investors will invest, investors can not only use financial statements to assess company performance, but can also use information about intellectual capital, which is about managing human capital in a company, a description of a business process that can demonstrate a company's ability to manage its business. So that investors can assess more closely how the conditions of the company.

Intellectual capital disclosure is not only useful for users of information but also for companies. Intellectual capital disclosure can provide value added for the company and one strategy that can be used to convince stakeholders about the ability of the company. Based on the results of the low disclosure rate of intellectual capital disclosure, and considering the benefits of intellectual capital disclosure, companies in Indonesia should be able to increase the level of disclosure of intellectual capital.

\section{CONCLUSION}

The research results indicate that only size variable (the size of the company), which has a significant influence on the ICD. Thus, it can be concluded that company size is a major predictor that may affect the variety of ICD practices on companies listed in the LQ-45 index. On the other hand, variables of profitability, leverage, liquidity, industry type, the size of the audit committee, and the composition of the board of commissioners bring no significant influence on the ICD.

Unfortunately, this study only analysed limited data, 81 companies, and the study period was only 2 years. Therefore, any future research may prolong the research period, add more variables, i.e. blockholder ownership, type of auditor, the breadth of information technology. In addition, the selection of proxies for the industry type should also consider the condition of a country, because some proxies for the industry type on developing countries and developed countries can be different.

\section{REFERENCES}

Alsaeed, K. (2006). The Association between Firm-Specific Characteristics and Disclosure. Managerial Auditing Journal, 21(5), $476-496$

Bontis, N. (2001). Assessing Knowledge Assets: A Review of the Models Used to Measure Intellectual Capital. International Journal of Management Reviews, 3(1), 41-60

Bozzolan, S., Favotto, F, \& Ricceri, F. (2003). Italian Annual Intellectual Capital Disclosure: An Empirical Analysis. Journal of Intellectual Capital, 4(4), 543-558

Bruggen, A, Vergauwen, P, \& Dao, M. (2009). Determinants of Intellectual Capital Disclosure: Evidence from Australia. Journal of Management Decision, 47(2), 233-245

Bukh, P. N, Nielsen, C., Gormsen, P., \& Mouritsen, J. (2005). Disclosure of Information on Intellectual Capital in Danish IPO Prospectuses. Accounting, Auditing and Accountability Journal, 18(6), 713-732 
Cooke, T. E. (1989). Voluntary Corporate Disclosure by Swedish Companies. Journal of International Financial Management and Accounting, 2(1), 13-2

Ghozali, I. (2006). Aplikasi Analisis Multivariate Dengan Program SPSS. Semarang: Badan Penerbit Universitas Diponegoro.

Hanafi, M. M, \& Halim, Abdul. (2009). Analisis Laporan Keuangan. Yogyakarta: UPP STIM YKPN

Hidalgo, R. L, Garcia-Meca, E, \& Martinez, I. (2011). Corporate Governance and Intellectual Capital Disclosure. Journal of Business Ethics, 100, 483-495

Jensen, M \& W. H. Meckling. (1976). Theory of The Firm: Managerial Behaviour, Agency Cost and Ownership Structure. Journal of Financial Economics, 3(4), 305-360

Li, J, Pike, R, \& Haniffa, R. (2008). Intellectual Capital Disclosure and Corporate Governance Structure in UK Firms. Accounting and Business Research, 38(2), 137-159

Lina. (2013). Faktor-faktor Penentu Pengungkapan Modal Intelektual. Media Riset Akuntansi, 3(1), 48-64

Nurunnabi, M, Hossain, M, \& Hossain, Md. (2011). Intellectual Capital Reporting in a South Asian Country: Evidence from Bangladesh. Journal of Human Resource Costing and Accounting, 15(3), 196-231

Oliveira, L., Rodrigues, L.M., \& Craig, R. (2006). Firm-Specific Determinants of Intangibles Reporting: Evidence from The Portuguese Stock Market. Journal of Human Resource Costing \& Accounting, 10(1), 11-33

Ousama, A. A, Fatima, A, \& Hafiz-Majdi, A, R. (2012). Determinants of Intellectual Capital Reporting. Journal of Accounting in Emerging Economies, 2(2), 119-139

Petty, R \& Cuganesan, S. (2005). Voluntary Disclosure of Intellectual Capital By Hongkong Companies: Examining Size, Industry, and Growth Effects Over time. Australian Accounting Review, 15(2), 40-50

Purnomosidhi, B. (2005). Analisis Empiris Terhadap Determinan Praktik Pengungkapam Modal Intelektual Pada Perusahaan Publik di BEJ. Tema, 6(2), 111-14

Ramadan, M \& Majdalany, G. (2013). The Impact of Corporate Governance Indicators on Intellectual Capital Disclosure: An Empirical Analysis from the Banking Sector in the United Arab Emirates. Paper presented in European Conference on Intellectual Capital. English

Sawarjuwono, T \& Kadir, A. P (2003). Intellectual Capital: Perlakuan, pengukuran dan pelaporan (sebuah Library Research). Jurnal Akuntansi \& Keuangan, 5(1), 35- 57

Singh, I \& Van der Zahn, J-L.W.M (2008). Determinants of Intellectual Capital Disclosure in Prospectuses of Initial Public Offerings. Accounting and Business Research, 38(5), 409-431,

Suhardjanto, D \& Wardhani, M. (2010). Praktik Intellectual Capital Disclosure Perusahaan Yang Terdaftar di Bursa Efek Indonesia. JAAI, 14(1), 71-85

Sveiby, K.E. (1997). The New Organizational Wealth: Managing and Measuring Knowledge Based Asset. San Fransisco, CA.

Taliyang, S.M, \& Jusop, M. (2011). Intellectual Capital Disclosure and Corporate Governance Structure: Evidence in Malaysia. International Journal of Business and Management, 6(12), 109-117

Uzliwati, L., Suhardjanto, D., \& Djati, K. (2014). The Characteristics of Audit Committee and Intellectual Capital Disclosure in Indonesia Banking Industry. GSTF International Journal on Business Review (GBR), 3(2), 18-24

Wallace, R. S. O., Naser, K., \& Mora, A. (1994). The Relationship Between Comprehensiveness of Corporate Annual Reports and Characteristics in Spain. Journal of Accounting and Public Policy, 25(97), 41-53

Whiting, R.H \& Woodcock, J. (2011). Firm Characteristics and Intellectual Capital Disclosure by Australian Companies. Journal of Human Resource Costing \& Accounting, 15(2), 102-126

Wolk, H. I, Tearney, M. G, \& Dodd, J. L. (2000). Accounting Theory: A Conceptual and Institutional Approach. Ohio: SouthWestern College Publishing

Zulkarnaen, E. I \& Mahmud, A. (2013). Pengaruh Good Corporate Governance Terhadap Luas Pengungkapan Intellectual Capital. Jurnal Dinamika Akuntansi, 5(1), 79-85 